\title{
Epstein-Barr Virus Antibody Positive
}

National Cancer Institute

\section{Source}

National Cancer Institute. Epstein-Barr Virus Antibody Positive. NCI Thesaurus. Code C150499.

An indication that antibodies that recognize the Epstein-Barr virus have been detected in a sample. 